\title{
Impact of Organisational and Psychological Factors on the Job Performance of Personnel in Private University Libraries in South-South Nigeria
}

\author{
Lilofa Osamiefan Ogiamien ${ }^{*}$, Roland Izuagbe ${ }^{2}$ \\ ${ }^{1}$ Benson Idahosa University Library, Benin City, Nigeria \\ ${ }^{2}$ Department of Library, Archival and Information Studies (LARIS), University of Ibadan, Ibadan, Nigeria \\ Email: "lilogy2015@gmail.com,rolec4u@yahoo.com
}

Received 11 March 2016; accepted 25 March 2016; published 29 March 2016

Copyright (C) 2016 by authors and OALib.

This work is licensed under the Creative Commons Attribution International License (CC BY). http://creativecommons.org/licenses/by/4.0/

(c) (i) Open Access

\begin{abstract}
The study examined organisational and psychological factors as correlates of job performance of personnel in private university libraries. Descriptive research design was adopted in the study. The total population of the study comprised of 83 respondents in the 8 private universities in South-South Nigeria. Since the population was small, total enumeration sampling technique was employed. The instrument adopted for the collection of data was the questionnaire. The questionnaire was structured based on 4-point Likert scale of Strongly Agree, Agree, Disagree and Strongly Disagree. Of the 83 copies of questionnaires administered, $73(94.0 \%)$ were found valid for analysis. The data collected were used to test the eight null hypotheses at 0.05 level of significance. The results of the study showed that organisational factors (organisational culture and organisational commitment) are stronger corrolates of job performance among personnel in private university libraries in South-South Nigeria than psychological factors (work motivation and self-esteem).
\end{abstract}

\section{Keywords}

Organisational Factors, Psychological Factors, Job Performance, Private University Libraries

Subject Areas: Education, Sociology

\section{Introduction}

Job performance is an important variable that has attracted researchers' attention with a view to unearthing hidden

${ }^{*}$ Corresponding author.

How to cite this paper: Ogiamien, L.O. and Izuagbe, R. (2016) Impact of Organisational and Psychological Factors on the Job Performance of Personnel in Private University Libraries in South-South Nigeria. Open Access Library Journal, 3: e2419.

http://dx.doi.org/10.4236/oalib.1102419 
but existing factors influencing the construct. According to [1], research on job performance using a variety of theoretical perspectives, such as personality, job characteristics and social networks, has been carried out. The progress made using these theoretical perspectives notwithstanding, job performance has remained a construct attracting huge investment from organisations. [2] citing [3] observes that the performance of a person on a job is considered a function of two different variables - the ability, skill or intelligence of the individual to perform the job and his/her motivation to use the ability or intelligence in the actual performance of the job. From this viewpoint, performance according to the author is the product of intelligence and motivation.

To be an excellent organisation, [4] states that workers' job performance remains an important factor to push forward. They pointed out that an organisation failure also depends, to a large extent, on the job performance of the individuals in that organisation. This is consequent upon the fact that several factors prompt employees to go above and beyond to produce great work which can positively affect an organisation's overall output [5]. This may have led [6] to conclude that job performance of individuals is crucial to the survival of any organisation.

There are numerous factors that determine the job performance of individuals in certain instances and settings. These may include empowerment, management behaviour, teamwork, motivation and work environment [7]. Broadly, while some of these concepts can be categorised as organisational, others are psychological. The consideration given to these variables by employees and organisations is theorised in this study to either have direct/ indirect (in) significant impact on job performance and by extension, job satisfaction.

On one hand, organisational factors are proposed in this paper as organisational culture and organisational commitment. This suggests that how well the corporate culture of an organisation is established and communicated to employees facilitating their working relationship. This is vital to the extent to which employees are willing to pledge allegiance and identify with an organisation. Psychological factors on the other hand, as proposed in this study, are work motivation and self-esteem. This study hypothesises that work motivation and selfesteem could influence the functions, attitude and characteristics of the human mind and in turn affect the behaviour and wellbeing of the individual.

Academic libraries are information support systems attached to post-secondary institutions of learning like universities, polytechnics and colleges of education (being they federal, state or private). Beside the overall goals of their parent institutions, these libraries also have their internal objectives. How well the management of the library harnesses her workforce (which is categorised into professional librarians, para-professionals and supportive staff) determine how well her objectives are met. For enhanced job performance, [8] advise that in addition to providing traditional library services, library professionals need to use non-traditional and innovative methods to meet highly specialised information needs of their users. The attainment of this objective hinges on: understanding the organisational culture of the library, ensuring high level of organisational commitment to library personnel through appropriate and adequate motivation that will result in good and positive self-view [6].

From preliminary investigation, library personnel in private university setting are faced with the challenges of poor working environment/conditions, inadequate staff training and development opportunities, poor career progression resulting in low self-worth which have adverse effect on their job performance. While some of these challenges may be largely due to systemic inefficiency, others may have psychological undertone. This may be prejudicial to library personnel enormous task of selection and acquisition of relevant information resources (print and electronic), processing, storage, maintenance and dissemination of same for the social and academic growth and development of the user-community they serve.

South-West geopolitical zone is the hub of higher institutions in Nigeria with overwhelming dominance of private universities. According to [9] there are 21 private universities in the region with additional 6 recently licensed-yet to commence operation. Beside number, the region prides what many considered "the best private universities in Nigeria”. Consequently, extensive research has been carried out in this region. Comparatively, there are 8 private universities in the South-South geopolitical zone of Nigeria. This region is the only oilproducing region in Nigeria hence; it is tagged "the richest in the country". Whether or not the terms of service in the private universities located in these regions are the same is not certain. It is against this backdrop that the study sets out to ascertain the significant impact of organisational factors (i.e. organisational culture and organisational commitment) as well as psychological factors (i.e. work motivation and self-esteem) on the job performance of personnel in private university libraries in South-South Nigeria.

\section{Objective}

The objectives of the study are to: 
1) ascertain the impact of organisational factors (organisational culture and organizational commitment) on the job performance of personnel in private university libraries in South-South Nigeria; and

2) determine the impact of psychological factors (work motivation and self-esteem) on the job performance of personnel in private university libraries in South-South Nigeria.

\section{Scope of the Study}

The study will examine the impact of organisational and psychological factors on the job performance of personnel in private university libraries. Geographically, the 8 private universities in the South-South geopolitical zone of Nigeria will provide the data and institutional setting. In terms of subject scope, the study will focus mainly on librarians and library officers.

\section{Literature Review}

\subsection{Organisational Factors and Job Performance of Personnel}

Organisationalculture is gaining support as a predictive and explanatory construct in organisational science [10], where; if properly managed and controlled is useful as a management tool for organisational effectiveness and performance [11]. Consistently, [12] asserts that orgainsational culture has assumed considerable importance in the 21st century, because of its impact on employee performance and job satisfaction. The usefulness of organisation culture in establishments lies in enabling organisations to acquire wisdom more quickly and efficiently than before and apply it. In essence, it provides a basis to maintaining a sustainable competitive advantage [13].

Organisational culture can be defined as the set of values, beliefs, attitudes, expectations, understandings, norms shared by members of an organization [14]. Similarly, organisational culture is the set of shared values, beliefs and norms that influence the way employees think, feel, and behave in the workplace [15]. These positions suggest that organisational norms and values have a strong effect on all those who are attached to the organisation [16]. For [17], organisational culture is a determinant of employee's performance as well as organisational successes because it brings about individual employees' innovativeness. The performance of employees helps to achieve organisational goals and must be measured in relation to culture of the organisation which influences employees' behaviour and decisions [18].

Literature has shown that management of human resources in a company is becoming increasingly important for firm performance and business vision achievement [19]. As regards organisational development, employees' performance is considered a backbone for the industry [20]. The relationship between organisational culture and performance has been suggested and an increasing body of evidence supports a linkage between an organisation's culture and its business performance [21]. From these positions therefore, understanding the values, norms and expectations of private university libraries commit personnel to exert extra effort towards attaining institutional objectives.

There is a connective between organisational commitment and job performance of employees. [22] opines that organisational commitment is an employee's attitude about his/her company. He maintains that the more favourable an individual's attitudes toward an organisation, the greater the individual's acceptance of the goals of the organisation, as well as their willingness to show more commitment on behalf of the organisation. This view is shared by [23] who argue that organisational commitment is regarded as an attitude, as it relates to individuals' mindsets about the organisation.

An attempt to understand and clarify the intensity and stability of an employee's dedication to an organisation has attracted considerable interest among researchers [24]. There is agreement among researchers that three dimensions of organisational commitment exist: continuance commitment (refers to commitment that is associated with the costs that employees perceive are related to leaving the organisation), normative commitment (reflects pressures on an employee to remain with an organisation resulting from organisational obligations) and affective commitment (which measures an employee's emotional attachment to, identification with and involvement in the organisation) [25]-[29].

But not all agreed on the significant effect of the variable on job performance. [30] opine that organisational commitment and its three dimensions present positive and negative relationships with age, sex, education, job status, and organisational tenure variables. The authors note further that the study of employee's job performance and organisational commitment is of foremost importance to top-level management of organisations. 
This is an indication that management of private university libraries should ensure high job performance among personnel by giving them reasons to take pride in organisational membership. [31] posits that committed employees who take pride in organisational membership, believe in the goals and values of the organisation and display high levels of performance and productivity.

Employees are among the most important determinants and leading factors that influence the success of an organisation in a competitive environment [31]. Commitment of employees can be an important instrument for improving the performance of an organisation [30]. But this is not achieved in a vacuum-employers' commitment to employees' needs and aspirations count. Personnel in private university libraries in this wise, will be considered committed if they are willing to maintain their association with their libraries and devote considerable effort to achieving organisational goals. The high levels of effort showed by employees with high levels of organisational commitment would lead to higher levels of performance and effectiveness of individual and the organization [32].

\subsection{Psychological Factors and Job Performance of Personnel}

Self-esteem is usually regarded as a person's overall evaluation of, or attitude toward, her/himself [33] [34]. Self-esteem according to [35] is the basic appraisal one makes of oneself, as it concerns the overall value that one places on oneself, as a person. Self-esteem can also be defined as 'a construct expressing the global relations toward the self' [36]. However, [37] argue that belief in one's capacity to change one's own situation is a major determining factor in the level of self-esteem. Over the years researchers have associated self-esteem with different dimensions like self-efficacy [37], core self-evaluations [38], organisational citizenship, collectivism and propensity to trust [39], Organisation-Based Self-Esteem (OBSE) and more closely, self-concept [40].

Self-esteem and self-concept are related concepts hence, they are often used interchangeably. [41] opine that individuals with poor self-concept often do not think properly and that people with low self-concept over-generalise the negative implications of failure. Hence, performance of low self-concept individuals decreases after a failure experience while the same experience does not alter the performance of high self-concept individuals. In a study conducted by [42] to find out the relationship between core self-evaluation traits and job satisfaction and job performance, it was found out that self-concept is a significant predictor of job satisfaction and job performance.

Within the motivational domain, one perspective that has been advanced is that self-esteem level or one's overall positive or negative evaluation of oneself should be related to job performance [43]. According to [44], individuals will be motivated to perform on a task or job in a manner which is consistent with their self-image, suggesting a positive main effect of self-esteem level on job performance. [45] citing [46] believe that to better understand when self-esteem level will have a relation with job performance, one must take a broader view of the self and consider not only self-esteem level (i.e., high or low self-esteem) but also self-esteem contingencies. The basic underlying theoretical tenet of self-esteem according to [47] is that individuals will develop attitudes and behave in ways that will maintain their level of self-esteem.

Like employees in profit-oriented organisations, personnel in private university libraries need to be encouraged for high job performance. This process is what [48] describe as motivation. [49] expand it further to mean the attribute that moves us to do or not to do something. From workplace perspective, [50] quoting Ray Williams, who writes for "Psychology Today", defines motivation as, "predisposition to behave in a purposeful manner to achieve specific, unmet needs and the will to achieve, and the inner force that drives individuals to accomplish personal organisational goals”.

Different things motivate different individuals. While some are motivated intrinsically, others are motivated extrinsically, but whatever motivates employees, it should be noted that motivation is a function of the inner drive that pushes individuals to act or perform in a given way [51] [6] citing [52], reports that an intrinsically motivated individual will be committed to his/her work to the extent to which the job inherently contains tasks that are rewarding to him or her. While an extrinsically motivated person will be committed to the extent that he/she can gain or receive external rewards for his or her job.

In a study to find out the relationship between rewards and employee performance in a cement industry in Pakistan, [53] found a significant relationship between extrinsic and intrinsic rewards and employee performance. According to them, both extrinsic (concrete and financial/material) and intrinsic (non-financial/material) rewards can be utilised positively to enhance job performance behaviour of workers. Thus, library managers must be able to apply extrinsic and intrinsic motivational strategies to engender good job performance among staff, in 
this way, good job performance translates to efficient and effective library services to their clientele and in away helping to achieve the mission and vision of the parent institutions.

[54] in a study conducted to determine the influence of work motivation on job performance of 82 recipients for excellent service found out that, high job performance is not solely dependent on work motivation alone rather, other factors such as good leadership, good working facilities and environment, as well as ability also play significant roles in enhancing good job performance. They also found that while work motivation was moderate, job performance was high. This informs their conclusion that there is no correlation between work motivation and job performance.

In contrast, [55] conducted a study in Nigeria on the implication of adequate motivation on workers' productivity in a power generating company. In a sample of 100 respondents, he concludes that salaries and other rewards were equally as important as other motivational factors. [56] explored, using integrative literature review mainly focused on business organisations, the factors affecting employee motivation and the relationship between organisational effectiveness and employee motivation. He empirically reveals the influence of empowerment and recognition on motivation and how in turn, these impacted on organisational effectiveness.

To increase efficiency, improve job satisfaction/performance, raise employee's morale, it is essential that an employee is viewed as a physiological, sociological, psychological, and egoistic creature [57]. The finding that average score of unfair treatment as a de-motivator is higher than that of fair treatment as a motivating factor is consistent with the fact that the negative impacts of unfairness are significantly stronger than the positive impacts of fairness [58]. With the present global economic trend, most employers of labour have realised that for their organisations to compete favourably, the performance of their employees goes a long way in determining the success of the organisation [59].

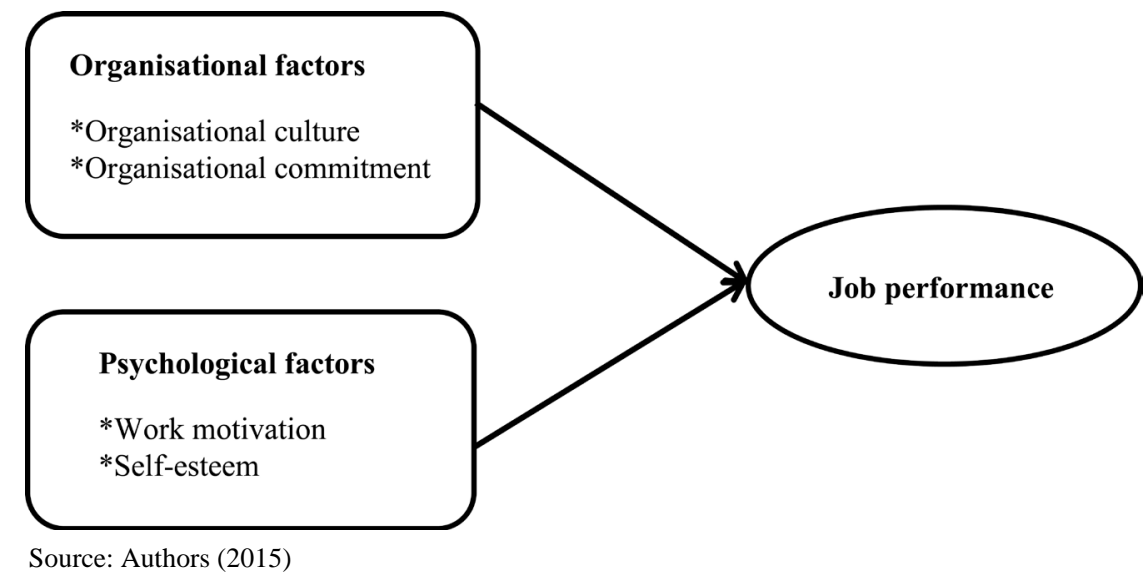

Conceptual model for organisational and psychological factors on job performance.

\section{Hypotheses}

$\mathbf{H}_{\mathbf{0 1}}$ There is no significant relationship between organisational factors (organisational culture and organisational commitment) and job performance of personnel in private university libraries in South-South Nigeria;

$\mathbf{H}_{\mathbf{0 2}}$ There is no significant relationship between psychological factors (work motivation and self-esteem) and job performance of personnel in private university libraries in South-South Nigeria.

\section{Methodology}

The descriptive survey design was adopted in this study. The population of this study comprised 48 librarians and 35 library officers making a total of 83 library personnel in all the 8 private university libraries in South-South Nigeria. Because the population is small, total enumeration was employed. This sampling technique is adopted when: 1) the population is small, 2) when there is no time constraint in carrying out the research, 3) the resources (human, money and materials) available for the study are inadequate and 4) the sole objective of the study is to take census of the elements in the population [60]. 1) above is the crux upon which the technique in anchored. The questionnaire method was adopted as the instrument for data collection for the study. The ques- 
tionnaire was divided into the following sections: Section A: bio-data of respondents. Section B: job performance of library personnel. Section C: organisational commitment of library personnel. Section D: organisational culture of responding libraries. Section E: work motivation of library personnel and Section F: self-esteem of library personnel.

Section A: seek to capture the bio-data of respondents; with items like gender, age, marital status, highest educational qualification, working experience, name of respondents' library.

Section B: Job performance scale.

The Value-based Performance Scale, developed by [61] was adapted. It was developed to evaluate public value-based performance and meant to elicit respondents' opinion on performance. Examples of the items are: "I constantly meet the formal performance requirements of my job" and "I perform my work tasks in an efficient way". The scale contained a 14-item with the following response patterns of Likert four-point scale of strongly agree $=4$, agree $=3$, disagree $=2$, and strongly disagree $=1$.

Section C: Organisational commitment scale

The Organisational Commitment Questionnaire-OCQ, developed by [62] was adapted. This is a 10-item scale aimed at capturing the extent to which employees identify with an organisation, their desire to remain in the organisation and their willingness to exert effort on behalf of the organisation. Sample items in the scale include "I am very loyal to this organisation" and "I really care about the fate of my organisation." The responses to these items were measured on a 5-point Likert scale of strongly agree $=5$, agree $=4$, undecided $=3$, disagree $=2$, and strongly disagree $=1$.

\section{Section D: Organisational culture scale}

The adapted questionnaire for this section is the Corporate Culture Scale, developed by [63]. It contains a 24-item self-assessment scale designed to help identify a corporate culture that best fits most closely with employees' personal values and assumptions. The scale contains statements like, I would prefer to work in an organisation: "where employees work well together in teams" and "where employees abide by company rules". The instrument was divided into "a" and "b" with the following scoring key: (2a) $-+\ldots(5 \mathrm{a})++\ldots(6 \mathrm{~b}) \ldots+$ (8b) -+ - (11b) - + - (12a).

\section{Section E: work motivation scale}

The Work Motivation Scale, developed by [64] was adapted. The scale was designed to obtain data from employees on what motivate them. It is a 12-item instrument with the following examples, "monetary incentives for a job well done" and "promotion or career development", scored using a 5-point Likert scale ranging from 1 $=$ very unimportant to $5=$ very important.

\section{Section F: Self-esteem scale}

The questionnaire adapted for this section is the Rosenberg Self-Esteem (RSE) Scale, developed by [65]. It is a 10-item scale designed to measure what people think of themselves. Items in the scale include: "I feel I do not have much to be proud of" and "I like to please or agree with others in order to be accepted". The instrument was scored on a 4-point Likert scale of strongly agree $=4$, agree $=3$, disagree $=2$ and strongly disagree $=1$.

\section{Reliability co-efficient}

Through a pre-test, the reliability coefficient of the instrument was determined. Since the study centres on private university libraries, it was deemed necessary to carry out the pre-test using a Federal University library. Consequently, 30 copies of the questionnaire were administered on library personnel in John Harris library (University of Benin, Edo State) and its faculty/departmental libraries. Upon retrieval of the instrument, the Cronbach's Alpha method was used to determine the reliability coefficients. The instrument exhibited high psychometric properties as follows: Job performance showed a reliability coefficient of 0.77; Organisational commitment displayed a reliability coefficient of 0.97 ; Organisational culture revealed a reliability coefficient of 0.81 ; Work motivation exhibited a reliability coefficient of 0.83 and Self-esteem had a reliability coefficient of 0.65 .

Table 1 presents the population of the study in terms of personnel's professional cadre, universities' year of establishment and location. From observation, professional librarians constitute the majority in comparison to library officers. The Table also reveals that BIU has the highest library personnel among the private universities in the South-South geopolitical zone with Igbinedion University, Okada being the oldest.

\section{Data Collection and Analysis}

Upon the collection of the data, the hypotheses were tested using inferential statistics such as correlation and multiple regression analyses with the aid of Statistical Package for Social Sciences (SPSS). 


\subsection{Demographic Characteristics of Respondents}

Table 2 shows that male respondents form the majority 45 (57.7\%) and the female 33 (42.3\%). Respondents

Table 1. Distribution of library personnel in private university libraries in south-south Nigeria.

\begin{tabular}{ccccccc}
\hline SN & University & Location & Year Est. & Librarian & Lib. Officer & Total \\
\hline 1 & Benson Idahosa University (BIU), Benin & Edo & 2002 & 13 & 6 & 19 \\
2 & Igbinedion University, Okada & Edo & 1999 & 8 & 3 & 11 \\
3 & Novena University, Ogume & Delta & 2005 & 7 & 4 & 11 \\
4 & Rhema University, Obeama-Asa & Rivers & 2009 & 3 & 7 & 10 \\
5 & Samuel Adegboyega University, Ogwa & Edo & 2011 & 4 & 5 & 9 \\
6 & Wellspring University, Evbuobanosa. & Edo & 2009 & 3 & 3 & 6 \\
7 & Western Delta University, Oghara & Delta & 2007 & 5 & 5 & 10 \\
8 & Obong University, Obong Ntak & A. Ibom & 2007 & 5 & & 2 \\
& Total & & & 48 & $\mathbf{3 5}$ & $\mathbf{8 3}$ \\
\hline
\end{tabular}

Table 2. Demographic information of respondents.

\begin{tabular}{|c|c|c|c|}
\hline SN & Item & Frequency & Percentage \\
\hline \multicolumn{4}{|c|}{ A. Gender } \\
\hline & Male & 45 & 57.7 \\
\hline & Female & 33 & 42.3 \\
\hline & Total & 78 & 100.0 \\
\hline \multicolumn{4}{|c|}{ B. Age } \\
\hline 1 & 25 - 35 Years & 21 & 26.9 \\
\hline 2 & 36 - 45 Years & 29 & 37.2 \\
\hline 3 & 46 - 55 Years & 17 & 21.8 \\
\hline \multirow[t]{2}{*}{4} & 55 and Above & 11 & 14.1 \\
\hline & Total & 78 & 100.0 \\
\hline \multicolumn{4}{|c|}{ C. Marital status } \\
\hline 1 & Single & 12 & 15.4 \\
\hline 2 & Married & 60 & 76.9 \\
\hline 3 & Divorced & 4 & 5.1 \\
\hline \multirow[t]{2}{*}{4} & Widowed & 2 & 2.6 \\
\hline & Total & 78 & 100.0 \\
\hline \multicolumn{4}{|c|}{ D. Working Experience (in years) } \\
\hline 1 & $1-5$ & 24 & 30.8 \\
\hline 2 & $6-10$ & 26 & 33.3 \\
\hline 3 & $11-15$ & 14 & 17.9 \\
\hline 4 & $16-20$ & 12 & 15.4 \\
\hline \multirow[t]{2}{*}{5} & Above 20 years & 2 & 2.6 \\
\hline & Total & 78 & 100.0 \\
\hline \multicolumn{4}{|c|}{ E. Highest University Qualification } \\
\hline 1 & OND/Diploma & 15 & 19.2 \\
\hline 2 & First Degree & 24 & 30.8 \\
\hline 3 & Masters & 37 & 47.4 \\
\hline \multirow[t]{2}{*}{4} & $\mathrm{PhD}$ & 2 & 2.6 \\
\hline & Total & 78 & 100.0 \\
\hline \multicolumn{4}{|c|}{ F. Job Status } \\
\hline 1 & Library Officer & 38 & 48.7 \\
\hline \multirow[t]{2}{*}{2} & Librarian & 40 & 51.3 \\
\hline & Total & 78 & 100.0 \\
\hline
\end{tabular}


between ages 36 to 45 constitute the majority with 29 (37.2\%) and 55 and above account for 11 (14.1\%). While an overwhelming majority of 60 (76.9\%) respondents are married, 2 (2.6\%) which form the least in the group are widowed. Respondents with working experience of between 6 to 10 years consist of the highest group with 26 (33.3\%), while the least is 2 (2.6\%). Masters degree holders constitute the highest group with 37 (47.4\%) and Ph.D was ranked the least with 2 (2.6\%). While Librarians are 40 (51.3\%) form the majority personnel in the region, library officers are 38 (48.7\%).

\subsection{Testing of Hypotheses}

$\mathbf{H}_{\mathbf{0 1}}$ There is no significant relationship between organisational factors (organisational culture and organisational commitment) and job performance of personnel in private university libraries in South-South Nigeria.

Table 3(a) shows the outcome of the Pearson product moment correlation with a mean score of 57.64 for organisational culture with S.D $=13.309$ while that of job performance is 64.8 and $\mathrm{SD}=13.8 . \mathrm{r}=0.762 ; \mathrm{p}<0.05$. This implies that there is a statistical significant relationship between organisational culture and job performance among personnel in private university libraries in South-South Nigeria.

Table 3(b) reveals that there is a significant relationship between organisational commitment and job performance of the respondents when $r=0.579, p<0.05$. This is an indication that respondents' organisational commitment level is high, which in turn led to high job performance among them. As a result, the null hypothesis is rejected and the implied alternative hypothesis is accepted. This shows that organisational factors (organisational culture and organisational commitment) significantly impact the job performance of personnel in private university libraries in South-South Nigeria.

$\mathbf{H}_{\mathbf{0 2}}$ There is no significant relationship between psychological factors (work motivation and self-esteem) and job performance of personnel in private university libraries in South-South Nigeria.

Table 4(a) indicates that there is a significant relationship $(r=0.671 ; \mathrm{p}<0.05)$ between work motivation and job performance among personnel of private university libraries in South-South Nigeria.

Table 4(b) indicates that the correlation coefficient " $r$ " between self-esteem and job performance is 0.037 and $\mathrm{P}>0.05$. Since $\mathrm{P}>0.05$, it implies that there is no significant relationship between self-esteem and job performance among personnel in private university libraries in South-South Nigeria. Accordingly, the stated null

Table 3. (a) Relationship between organisational culture and job performance among personnel in private university libraries; (b) Relationship between organisational commitment and job performance among personnel in private university libraries.

(a)

\begin{tabular}{ccccccc}
\hline Variable & $\mathbf{N}$ & $\mathbf{X}$ & SD & R & P & Remark \\
\hline Organisational culture & 78 & 57.64 & 13.309 & & & Sig. \\
Job performance & 78 & 64.8 & 13.803 & 0.762 & 0.0014 & \\
\hline
\end{tabular}

(b)

\begin{tabular}{ccccccc}
\hline Variable & N & X & SD & R & Remark \\
\hline Organisational commitment & 78 & 47.1 & 11.889 & 0.579 & 0.043 \\
Job performance & 78 & 64.8 & 13.803 & Sig. \\
\hline
\end{tabular}

Table 4. (a) Relationship between work motivation and job performance among personnel in private university libraries; (b) Relationship between self-esteem and job performance among library personnel in private university libraries.

(a)

\begin{tabular}{cccccccc}
\hline Variable & N & $\mathbf{X}$ & SD & R & P & Remark \\
\hline Work motivation & 78 & 44.9 & 12.981 & \multirow{2}{*}{0.671} & 0.012 & Sig. \\
Job performance & 78 & 64.8 & 13.803 & & \\
\hline
\end{tabular}

(b)

\begin{tabular}{ccccccc}
\hline Variables & N & $\mathbf{X}$ & SD & R & P & Remark \\
\hline Self-esteem & 78 & 44.6 & 10.778 & \multirow{2}{*}{0.037} & 0.065 & N.S \\
Job performance & 78 & 64.8 & 13.803 & & \\
\hline
\end{tabular}


hypothesis is accepted and the implied alternative hypothesis is accepted. This shows that self-esteem will not significantly impact the job performance of personnel in private university in South-south Nigeria.

\section{Discussion of Findings}

The most striking finding of this study in relation to the stated hypotheses is that organisational factor is a stronger facilitator of job performance than psychological factor among personnel in private university libraries in South-South Nigeria. This conclusion was drawn from the analyses measuring the relationships between organisational culture and job performance as well as that of organisational commitment and job performance. With reference to $\mathrm{H}_{1}$, the study found that organisational culture (a component of organisational factor) has the strongest relationship on job performance among personnel in private university libraries in South-South Nigeria. This finding corroborates that of [66] who found that there is a direct significant relationship between organisational culture and job performance. He also found that a strong employee-friendly organisational culture can lead to effective employee performance. Consistently, [67] report that organisational culture and performance are two variables that are significantly correlated. The finding of [68] [69] however suggests that the relationship between many cultural attributes and employees' performance has not been consistent over time. Agreeably, [70] reveals that the evidence regarding the exact nature of this relationship between organisational culture and job performance is mixed. These inconsistencies notwithstanding, the finding of this study agrees with the streams of research that support a positive and direct relationship between organizational culture and job performance.

Next to organisational culture in terms of significant relationship with job performance, is organisational commitment (another component of organisational factor) as shown in Table 3(b). This implies that personnel in private university libraries in South-South Nigeria are highly committed to their libraries. This finding is congruent with that of [71] who reveal that a significant relationship exists between the two variables. A consensus among researchers on the relationship is non-existent. Within the Nigerian context for example, [72] reports that as regards organisational commitment of Nigerian workers (personnel in private university libraries inclusive), there is divergence of opinions among researchers; while some believed that Nigerian workers are not committed to their organisations, others believed that they are, it is the organisations that do not show commitment to the plight of workers [73]. It should be understood therefore that personnel commitment to organisation is not achieved in isolation; it is a product of a process-motivation.

The study also shown that there is a significant relationship between work motivation and job performance among personnel in private university libraries in South-South Nigeria. This finding is consistent with that of [52] who report that motivation (extrinsic and intrinsic) has significant influence on employees' job performance. Private universities are profit-oriented, their personnel could therefore be regarded as a means of achieving this aim - the more they are motivated, the better their institutions. For [74], a motivated person is always ready to act. This is because inadequately and inappropriately motivated personnel tend to express their displeasure through poor performance and non-commitment to their job [52]. This may not be unconnected to the findings of [75] who reveal that majority of their respondents (47\%) show that their level of motivation affects their performance positively and (23.7\%) indicate that their motivational level affects their performance negatively.

In contrast to previous findings, there is no positive and significant relationship between self-esteem and job performance of personnel in private university libraries in South-South Nigeria. Corroborating this position, [76] show that self-esteem seems to have little or no direct relationship with task performance. From the academic perspective, [77] reveal significant though weak positive relationship between self-esteem and university performance. In contrast, [78] argue that there is a significant relationship between self-esteem, motivation and task performance of professional and Para-professional librarians in Nigerian university libraries. From this finding, it is assume that personnel in private university libraries do not consider self-esteem a major facilitator of job performance. This could mean that other factors which were not covered by this study may compliment the perceived role of self-esteem in relation to job performance of personnel in private university libraries in South-South Nigeria.

\subsection{Significance of the Study}

A review of the literature on job performance and its perceived predictors reveals that a lot has been done to identify what determines high job performance among different study groups in different organisational settings. Obviously, there is insufficient empirical evidence from literature proposing the current thought of the authors. 
As envisaged therefore, the findings of this study will fill this gap and make significant addition to literature in the fields of librarianship, industrial and personnel psychology. Similarly, the study intends providing a framework for understanding high job performance indicators. This understanding will spur library managers into building strong organisational culture that will encourage high commitment as well as positive self-perception among library personnel.

\subsection{Limitation of the Study}

In thisstudy,attempt has been made to ensure thoroughness. But since no research endeavour is perfect, the authors cannot claim comprehensiveness - several limitations abound. The crux of the inadequacies associated with this study which could prevent drawing of rigid conclusions is the small population size, despite using a whole geopolitical zone. This in turn informs the used of total enumeration technique which may not be appropriate for a study of this nature if the population was larger.Also, the study did not take all elements of organisational factors into cognisance. For example, hierarchies,work settings, autonomy andorganisationalpoliticswere not considered in this study as parts of organisational factors. Organisationalcommitment on the other hand was measured as organisational factor and not as individual response to organisational factor.

\subsection{Suggestions for Further Studies}

To make up for the aforementioned drawbacks, the study suggests that subsequent effort should be tilted towards a larger population (probably in public university environment) for making definitive conclusions. Organisationalfactors should be extended to include organisationalrules and procedures, politics, hierarchies, work setting and autonomy as predictors of job performance of library personnel with organisational commitment as individual responsiveness to organisational factors.

\section{Conclusion}

This study offers empirical proof for organisational factors (organisational culture and organisational commitment) as the strongest correlates of job performance among personnel in private university libraries than psychological factors (work motivation and self-esteem). This implies that the corporate culture or an organisation and personnel's identification with such organisation play dominant role in personnel's improved job performance than rewards and personal self-assessment. Similarly, the study lends theoretical support to the stream of studies that theorised that employees' job performance is paramount to organisational survival or failure.

\section{Recommendations}

Based on the findings of this study, the following recommendations are made:

1) Since job performance is such an important driver of organisational success, management of private university libraries should strive to sustain high level of job performance by creating a scintillating working environment, ensuring good working conditions and human capacity development.

2) Since the psychological constructs examined in this study showed weaker relationship to job performance, in comparison to organisational factors, management of private university libraries should establish an effective reward system to recognise and encourage hard work and outstanding performance. And always be on the lookout for demotivating factors in their institutions that will not bring about the attainment of organisational objectives.

3) Also, personnel in private university libraries should be made to understand and imbibe the culture of being positive about the "self", since it is vital for effective customer service. This can be achieved in part by taking into account the feelings, desires and aspirations of personnel.

\section{References}

[1] Zhang, X. and Venkatesh, V. (2014) Explaining Employee Job Performance: The Role of Online and Offline Workplace Communication Networks. MIS Quarterly, 37, 695-715.

[2] Yaya, J.A. (2007) Work Motivation and Emotional Intelligences Correlates as Librarians' Job Performance in Selected University Libraries in South-South, Nigeria. Unpublished MLIS dissertation submitted to the department of Library, Archival and Information Studies (LARIS), University of Ibadan, Ibadan. 
[3] Vroom, V.H. (1964) Work and Motivation. Wiley, New York.

[4] Saetang, J., Sulumnad, K., Thampitak, P. and Sungkaew, T. (2010) Factors Affecting Perceived Job Performance among Staff: A Case Study of Ban Karuna Juvenile Vocational Training Centre for Boys. The Journal of Behavioural Sciences, 5, 33-45.

[5] Kaufman, T., Christensen, D.T. and Newton, A. (2015) Employee Performance: What Causes Great Work? National Research by Cicero Group. Commissioned by the O. C. Tanner Institute.

[6] Aboyade, W.A. (2013) Influence of Work Motivation, Emotional Intelligence and Self-Concept on Job Performance among Library Workers in Federal Universities in Nigeria. Ph.D. Thesis submitted to the Department of Library, Archival and Information Studies (LARIS), Faculty of Education, University of Ibadan, Ibadan.

[7] Saifullah, N., Alam, M. and Zafar, M.W. (2015) Job Satisfaction: A Contest between Human and Organisational Behaviour. International Journal of Economic Research, 6, 45-51.

[8] Yaya, J.A., Achonna, A.U. and Osisanwo, T. (2014) Competitive Intelligence: A Tool for Effective Job Performance in Academic Library. Sky Journal of Educational Research, 2, 20-27.

[9] National University Commission (NUC) (2015) List of Private Universities. https://www.students.com.ng/list-of-accredited-private-universities-in-nigeria

[10] Liu, A.N.M., Shuibo, Z. and Meiyung, L. (2006) A Framework for Assessing Organisational Culture of Chinese Construction Enterprises. Engineering, Construction and Architectural Management, 13, 327-342. http://dx.doi.org/10.1108/09699980610680153

[11] Olanipekun, A.O., Aje, I.O. and Abiola-Falemu, J.O. (2013) Effects of Organisational Culture on the Performance of Quantity Surveying Firms in Nigeria. International Journal of Human and Social Sciences, 3, 1-10.

[12] Dwirantwi, E.A. (2012) Organisational Culture and Its Effect on Productivity; The Case Study of La Community Bank. A Thesis submitted to the Institute of Distance Learning, Kwame Nkrumah University of Science and Technology in Partial Fulfillment of the Requirements for the Degree of Commonwealth Executive Masters of Public Administration.

[13] Shihhosseini, S. and Nadi, M.A. (2015) Analyzing the Relationship of Organisational Trust and Organisational Culture with Knowledge Sharing Behaviour in Teachers of Second Intermediate Period. Educational Research Review, 10, 722-727. http://dx.doi.org/10.5897/ERR2015.2125

[14] Daft, R.L. and Marcic, D. (2009) Management: The New Workplace. Evans Publishing Group, Florence.

[15] Schein, E.H. (2011). Leadership and Organisational Culture. Wiley, New York.

[16] Stewart, D. (2010) Growing the Corporate Culture. https://www.wachovia.com/foundation/v/index.jsp?vgnextoid=ab411f07760aa110VgnV CM1000004b0d1872

[17] Imran, R., Saeed, T., Anis-Ul-Haq, M. and Fatima, A. (2010) Organisational Climate as a Predictor of Innovative Work Behaviour. African Journal of Business Management, 4, 3337-3343.

[18] Owoyemi, O.O. and Ekwoaba, J.O. (2014) Organisational Culture: A Tool for Management to Control, Motivate and Enhance Employees’ Performance. American Journal of Business and Management, 3, 168-177. http://dx.doi.org/10.11634/216796061403514

[19] Ahmed, M.A. (2012) The Role of Self-Esteem and Optimism in Job Satisfaction among Teachers of Private Universities in Bangladesh. Asian Business Review, 1, 89-95.

[20] Shahzad, F., Luqman, R.A., Khan, A.R. and Shabbir, L. (2012) Impact of Organisational Culture on Organisational Performance: An Overview. Institution of Interdisciplinary Business Research, 3, 12-18.

[21] Zakari, M., Poku, K. and Owusu-Ansah, W. (2013) Organisational Culture and Organisational Performance: Empirical Evidence from the Banking Industry in Ghana. International Journal of Business, Human and Technology, 3, 95-107.

[22] Gbadamosi, G. (2003) HRM and the Commitment Rhetoric: Challenges for Africa. Management Decision, 41, 274-280. http://dx.doi.org/10.1108/00251740310475218

[23] Lumley, E.J., Coetzee, M., Tladinyane, R. and Ferreira, N. (2011) Exploring the Job Satisfaction and Organisational Commitment of Employees in the Information Technology Environment. South African Business Review, 15, 100-118.

[24] Lumley, E. (2010) Exploring the Relationship between Career Anchors and Organisational Commitment. Unpublished Master; Dissertation, submitted to the Department of Industrial and Organisational Psychology, University of South-Africa, Protoria.

[25] Karrasch, B.V. (2003) Antecedents and Consequences of Organisational Commitment. Military Psychology, 15, 225-236. http://dx.doi.org/10.1207/S15327876MP1503_05

[26] Turner, B.A. and Chelladurai, P. (2005) Organisational and Occupational Commitment, Intention to Leave, and Perceived Performance of Intercollegiate Coaches. Journal of Sport Management, 19, 193-211.

[27] Greenberg, J. (2005) Managing Behaviour in Organisations. 4th Edition, Prentice-Hall, Englewood. 
[28] Boehman, J. (2006) Affective, Continuance, and Normative Commitment among Student Affairs Professionals. Unpublished Doctoral Dissertation, North Carolina State University, Raleigh.

[29] Canipe, B. (2006) Relationships among Trust, Organisational Commitment, Perceived Organisational Support, and Turnover Intentions. Unpublished Doctoral Dissertation.

[30] Memari, N., Mahdieh, O. and Marnani, A.B. (2013) The Impact of Organisational Commitment on Employees Job Performance. “A Study of Meli Bank”. Interdisciplinary Journal of Contemporary Research in Business, 5, 344-349.

[31] Ismail, N. (2012) Organisational Commitment and Job Satisfaction among Staff of Higher Learning Education Institutions in Kelantan. Master of Human Resource Management, Othman Yeop Abdullah Graduate School College of Business, Universiti Utara Malaysia (UUM), Sintok.

[32] Sharma, J.P. and Bajpai, N. (2010) Organisational Commitment and Its Impact on Job Satisfaction of Employees: A Comparative Study in Public and Private Sector in India. International Bulletin of Business Administration, 9, 7-19.

[33] Leary, M.R. and MacDonald, G. (2003) Individual Differences in Trait Self-Esteem: A Theoretical Integration. In: Leary, M. and Tangney, J., Eds., Handbook of Self and Identity, Guildford Publications, New York, 401-418.

[34] Pyszczynski, T., Greenberg, J., Solomon, S., Arndt, J. and Schimel, J. (2004) Why Do People Need Self-Esteem? A Theoretical and Empirical Review. Psychology Bulletin, 130, 435-468. http://dx.doi.org/10.1037/0033-2909.130.3.435

[35] Bellou, V., Chitiris, L. and Bellou, A. (2005) The Impact of Organisational Identification and Self-Esteem on Organisational Citizenship Behaviour: The Case of Greek Public Hospitals. Operational Research International Journal, 5, 305-318. http://dx.doi.org/10.1007/BF02944315

[36] Classen, C.A., Sherrilene, C., Velozo, W. and Mann, W.C. (2007) The Rosenberg Self-Esteem Scale as a Measure of Self-Esteem for the Noninstitutionalized Elderly. Clinical Gerontologist, 31, 77-93. http://dx.doi.org/10.1300/J018v31n01_06

[37] Creed, P.A., Bloxsome, T.D. and Johnston, K. (2001) Self-Esteem and Self-Efficacy Outcomes for Unemployed Individuals Attending Occupational Skills Training Programs. Community, Work \& Family, 4, 285-303. http://dx.doi.org/10.1080/01405110120089350

[38] Bipp, T. (2010) What Do People Want from Their Jobs? The Big Five, Core Self-Evaluations and Work Motivation. International Journal of Selective Assessment, 18, 28-39. http://dx.doi.org/10.1111/j.1468-2389.2010.00486.x

[39] Dyne, L.V., Vandewalle, D., Kostova, T., Latham, M.E. and Cummings, I.L. (2000) Collectivism, Propensity to Trust and Self-Esteem as Predictors of Organisational Citizenship in a Non-Work Setting. Journal of Organisational Behaviour, 21, 3-23. http://dx.doi.org/10.1002/(SICI)1099-1379(200002)21:1<3::AID-JOB47>3.0.CO;2-6

[40] Carson, K.D., Carson, P.P., Lanford, H. and Roe, C.W. (1997) The Effects of Organisation-Based Self-Esteem on Workplace Outcomes: An Examination of Emergency Medical Technicians. Public Personnel Management, 26, 139155. http://dx.doi.org/10.1177/009102609702600111

[41] Judge, T.A., Erez, A. and Bono, J.E. (1998) The Power of Being Positive: The Relation between Positive Self-Concept and Job Performance. Human Performance, 11, 167-187. http://dx.doi.org/10.1080/08959285.1998.9668030

[42] Judge, T.A. and Bono, J.E. (2001) Relationship of Core Self-Evaluations Traits-Self-Esteem, Generalized Self-Efficacy, Locus of Control, and Emotional Stability-With Job Satisfaction and Job Performance: A Meta-Analysis. Journal of Applied Psychology, 86, 80-92. http://dx.doi.org/10.1037/0021-9010.86.1.80

[43] Pierce, J.L. and Gardner, D.G. (2004) Self-Esteem within the Work and Organisational Context: A Review of the Organisation-Based Self-Esteem Literature. Journal of Management, 30, 591-622. http://dx.doi.org/10.1016/j.jm.2003.10.001

[44] Korman, A.K. (2001) Self-Enhancement and Self-Protection: Toward a Theory of Work Motivation. In: Erez, M., Kleinbeck, U. and Thierry, H., Eds., Work Motivation in the Context of a Globalizing Economy, Lawrence Erlbaum Associates, Mahwah, 121-130.

[45] Ferris, D.L., Lian, H., Brown, D.J. and Pang, F.X.J. (2010) Self-Esteem and Job Performance: The Moderating Role of Self-Esteem Contingencies. Personnel Psychology, 63, 561-593. http://dx.doi.org/10.1111/j.1744-6570.2010.01181.x

[46] Crocker, J., Luhtanen, R.K., Cooper, M.L. and Bouvrette, A. (2003) Contingencies of Self-Worth in College Students: Theory and Measurement. Journal of Personality and Social Psychology, 85, 894-908. http://dx.doi.org/10.1037/0022-3514.85.5.894

[47] Qureshi, J.A., Shahjehan, A., Zeb, F. and Saifullah, K. (2011) The Effect of Self-Esteem and Organisational Identification on Organisational Citizenship Behaviour: A Case of Pakistani Public Sector University. African Journal of Business Management, 5, 3448-3456. http://www.academicjournals.org/journal/AJBM/article-full-textpdf/923C61036558

[48] Guay, F., Chanal, J., Ratelle, C.F., Marsh, H.W., Larose, S. and Boivin, M. (2010) Intrinsic, Identified, and Controlled Types of Motivation for School Subjects in Young Elementary School Children. British Journal of Educational Psychology, 80, 711-735. http://dx.doi.org/10.1348/000709910X499084 
[49] Lai, E.R. (2011) Motivation: A Literature Review. Pearson Research Report.

[50] Burton, C.G. (2012) The Development of Metrics for Community Resilience to natural disasters. A thesis submitted in Partial Fulfillment of the Requirements for the Degree of Doctor of Philosophy in Geography, College of Arts and Sciences, University of South Carolina, Columbia.

[51] Mawoli, M.A. and Babandako, A.Y. (2011) An Evaluation of Staff Motivation, Dissatisfaction and Job Performance in an Academic Setting. Australian Journal of Business and Management Research, 1, 1-13.

[52] Ajila, C. and Abiola, A. (2004) Influence of Rewards on Workers Performance in an Organisation. Journal of Social Science, 8, 7-12.

[53] Qureshi, M.I., Zaman, K. and Shah, I.A. (2010) Relationship between Rewards and Employee’s Performance in the Cement Industry in Pakistan. Journal of International University Research, 10, 19-29.

[54] Elias, H. and Yaakub, N.F. (2009) Work Motivation and Job Performance: Case of Recipients for Excellent Service in a Higher Education. Malaysian Management Review, 11, 343-352.

[55] Ehiorobo, I.R. (2004) The Implication of Adequate Motivation on Workers' Productivity in an Organization. A Dissertation Submitted to St. Clements University, in Partial Fulfilment of the Requirements for the Award of Doctor of Philosophy.

[56] Manzoor, Q.A. (2010) Impact of Employee Motivation and Organizational Effectiveness. European Journal of Business and Management, 3, 36-44.

[57] Mallaiah, T.Y. and Yadapadithaya, P.S. (2009) Intrinsic Motivation of Librarians in University Libraries in Karnataka. DESIDOC. Journal of Library \& Information Technology, 29, 36-42. http://dx.doi.org/10.14429/djlit.29.250

[58] Diener, E. and Chan, M.Y. (2011) Happy People Live Longer: Subjective Well-Being Contributes to Health and Longevity. Applied Psychology: Health and Well-Being, 3, 1-43. http://dx.doi.org/10.1111/j.1758-0854.2010.01045.x

[59] Akanbi, P.A. (2012) Influence of Extrinsic and Intrinsic Motivation on Employees Performance. www.ilo.org

[60] Popoola, S.O. (2012) Conceptual Model Building and Research Design. A Paper Presented on Research Methods at Chapel Seminar Series of School of Postgraduate Studies, Ilishan-Remo, 3 December 2012, 8-9.

[61] Loon, N.V., Vandenabeele, W. and Leisink, P. (2013) Public Value-Based Performance: The Development and Validation of a Measurement Scale. 11th Public Management Research Conference, Madison, 20-22 June 2013, 2-4.

[62] Mowday, R.T., Steers, R. and Porter, L.W. (1979) The Measurement of Organizational Commitment. Journal of Vocational Behavior, 14, 224-247. http://dx.doi.org/10.1016/0001-8791(79)90072-1

[63] McShane, S.L. (2000) Organisational Culture. In: McShane, S.L., Eds., Canadian Organizational Behavior, Chap. 16, 511-522. http://www.uni-graz.at/iimwww/iimwww/orgculture.pdf

[64] Curtis, C.R., Upchurch, R.S. and Severt, D.E. (2009) Employee Motivation and Organisational Commitment: A Comparison of Tipped and Nontipped Restaurant Employees. International Journal of Hospitality and Tourism Administration, 10, 253-269. www.tandfonline.com/doi/abs/10.1080/15256480903088469 http://dx.doi.org/10.1080/15256480903088469

[65] Rosenberg, M. (1965) Society and the Adolescent Self-Image. Princeton University Press, Princeton.

[66] Ojo, O. (2008) Organisational Culture and Performance: Empirical Investigation of Nigerian Insurance Companies. Manager Journal, 8, 118-127.

[67] Imam, A., Abbasi, A.S., Muneer, S. and Qadri, M.M. (2013) Organizational Culture and Performance of Higher Educational Institutions: The Mediating Role of Individual Readiness for Change. European Journal of Business and Management, 5, 23-34.

[68] Sorensen, J.B. (2002) The Strength of Corporate Culture and the Reliability of Firm Performance. Administrative Science Quarterly, 47, 70-91. http://dx.doi.org/10.2307/3094891

[69] Agwu, M.O. (2014) Organisational Culture and Employees Performance in the National Agency for Food and Drugs Administration and Control (NAFDAC) Nigeria. Global Journal of Management and Business Research: Administration and Management, 14, 1-10.

[70] Lunenburg, F.C. (2011) Organisational Culture-Performance Relationships: Views of Excellence and Theory Z. National Forum of Educational Administration and Supervision Journal, 29, 1-10.

[71] Meyer, J.P. and Allen, N.J. (2007) Commitment in the Workplace: Theory, Research, and Application. Sage, Thousand Oaks.

[72] Olugbile, O. (1996) Nigeria at Work: A Survey of the Psychology of Work among Nigerian Guarantee Trust Bank Plc Lagos. Unpublished PhD Thesis, University of Lagos, Lagos.

[73] Alarape, A.I. and Akinlabi, F.M. (2000) Influence of Perceived Organisational Support and Discretionary Treatment on Work Attitude of Industrial Workers. African Journal for the Psychological Study of Social Issues, 5, 23-36. 
[74] Kotler, P. and Keller, K.I. (2010) Marketing Management. 12th Edition, Dorling Kindersley Pvt. Ltd., New Delhi.

[75] Lamptey, R.B., Boateng, M.S. and Antwi, I.K. (2013) Motivation and Performance of Librarians in Public Universities in Ghana. Library Philosophy and Practice (e-journal).

[76] Baumeister, R.F., Campbell, J.D., Krueger, J.I. and Vohs, K.D. (2003) Does High Self-Esteem Cause Better Performance, Interpersonal Success, Happiness, or Healthier Lifestyles? Psychological Science in the Public Interest, 4, 1-44. http://dx.doi.org/10.1111/1529-1006.01431

[77] Davies, J. and Brember, I. (1999) Reading and Mathematics Attainments and Self-Esteem in Years 2 and 6-An Eight-Year Cross-Sectional Study. Educational Studies, 25, 145-157. http://dx.doi.org/10.1080/03055699997873

[78] Nwosu, O.C., Florence, F.U. and Okeke, I.E. (2013) Self-Esteem and Perceived Levels of Motivation as Correlates of Professional and Para-Professional Librarians' Task Performance in Universities of South-East, Nigeria. International Journal of Human and Social Sciences, 2, 52-55. 